\title{
The small molecule specific EphB4 kinase inhibitor NVP-BHG712 inhibits VEGF driven angiogenesis
}

\author{
Georg Martiny-Baron • Philipp Holzer • Eric Billy • Christian Schnell • \\ Joseph Brueggen • Mireille Ferretti • Niko Schmiedeberg • Jeanette M. Wood • \\ Pascal Furet $\cdot$ Patricia Imbach
}

Received: 13 July 2010/Accepted: 5 August 2010/Published online: 29 August 2010

(C) The Author(s) 2010. This article is published with open access at Springerlink.com

\begin{abstract}
EphB4 and its cognitive ligand ephrinB2 play an important role in embryonic vessel development and vascular remodeling. In addition, several reports suggest that this receptor ligand pair is also involved in pathologic vessel formation in adults including tumor angiogenesis. Eph/ephrin signaling is a complex phenomena characterized by receptor forward signaling through the tyrosine kinase of the receptor and ephrin reverse signaling through various protein-protein interaction domains and phosphorylation motifs of the ephrin ligands. Therefore, interfering with EphR/ephrin signaling by the means of targeted gene ablation, soluble receptors, dominant negative mutants or antisense molecules often does not allow to discriminate between inhibition of Eph/ephrin forward and reverse signaling. We developed a specific small molecular weight kinase inhibitor of the EphB4 kinase, NVPBHG712, which inhibits EphB4 kinase activity in the low nanomolar range in cellular assays showed high selectivity for targeting the EphB4 kinase when profiled against other
\end{abstract}

G. Martiny-Baron $(\bowtie)$

Novartis Institutes for Biomedical Research, Expertise Platform Kinases, Novartis Campus, Fabrikstrasse 16, WJS152.1.72.2, 4056 Basel, Switzerland

e-mail: georg.martiny-baron@ novartis.com

P. Holzer · N. Schmiedeberg · P. Furet · P. Imbach Novartis Institutes for Biomedical Research, Global Discovery Chemistry, Basel, Switzerland

E. Billy $\cdot$ C. Schnell $\cdot$ J. Brueggen $\cdot$ M. Ferretti

Novartis Institutes for Biomedical Research, Oncology, Basel, Switzerland

Present Address:

J. M. Wood

S*BIO Pte Ltd, Singapore, Singapore kinases in biochemical as well as in cell based assays. Furthermore, NVP-BHG712 shows excellent pharmacokinetic properties and potently inhibits EphB4 autophosphorylation in tissues after oral administration. In vivo, NVP-BHG712 inhibits VEGF driven vessel formation, while it has only little effects on VEGF receptor (VEGFR) activity in vitro or in cellular assays. The data shown here suggest a close cross talk between the VEGFR and EphR signaling during vessel formation. In addition to its established function in vascular remodeling and endothelial arterio-venous differentiation, EphB4 forward signaling appears to be an important mediator of VEGF induced angiogenesis since inhibition of EphB4 forward signaling is sufficient to inhibit VEGF induced angiogenesis.

Keywords Angiogenesis - EphB4 - EphrinB2 - VEGF . Protein kinase inhibitor

\section{Introduction}

Formation of the vascular network is tightly controlled by a variety of growth factors and their appropriate receptors. Thus, receptor tyrosine kinases which are expressed on endothelial cells (ECs) have been shown to be crucial for embryonic vasculogenesis and angiogenesis (for review see [1]). While VEGF (vascular endothelial growth factor) receptors activated by VEGF mainly contribute to very early steps of vasculogenesis and angiogenesis including differentiation of EC precursors and formation of a primitive vascular network, two other receptor tyrosine kinases and their ligands, namely the angiopoietin/TIE-2 (tyrosine kinase with Ig like loops and EGF like repeats 2) and ephrinB2/EphB4 respectively, contribute to later steps of vascular development like vessel branching and vessel 
maturation and the recruitment of EC associated pericytes/ smooth muscle cells.

The Eph receptors (receptor cloned from erythropoietinproducing hepatocellular carcinoma) are the largest subfamily of receptor tyrosine kinases and are activated by their cell surface bound ligands of the equally large ephrin family (Eph receptor interacting protein). Both, receptors and ligands are divided into an A- and B-class; nine EphA receptors bind to five A-ligands and five EphB receptors bind to three ephrinB ligands. Like for other receptor tyrosine kinases (RTKs), receptor signaling is initiated by oligomerization and tyrosine-phosphorylation of the receptor. Unlike other ligand/RTK pairs, also ephrin ligands can transmit signals upon receptor engagement, a phenomenon which is called bi-directional signaling. EphrinB-ligands, which possess a transmembrane and cytoplasmatic domain, get tyrosine-phosphorylated upon receptor binding which induces ephrin reverse signaling in addition to the receptor forward signaling (for review see [2]). Although quite promiscuous interactions between EphRs and their ligands the ephrins have been observed, ephrinB2 is the only known ligand for EphB4. EphB4 and ephrinB2 were the first genes discovered to be differentially expressed in arterial and venous endothelium and genetic ablation of either EphB4 or ephrinB2 are embryonic lethal due to impaired vascular remodeling and arrest of endothelial differentiation [3, 4].

Over-expression of EphB4 has been reported for several tumor types including breast, colon, bladder, endometrium and ovary [5-10]. The role of EphB4 in cancer is not fully elucidated. On the one side, EphB4 expressed on tumor cells can interact with ephrinB2 of the endothelium and thereby promotes tumor angiogenesis and growth [11], on the other hand EphB4 has been described to either promote or suppress tumor growth, depending on the tumor type and tumor model which has been looked at [5, 12-15]. The paradoxes of EphB4 signaling in cancer has been recently discussed [16].

Despite this, EphB4 and ephrinB2 signaling has been proven to be involved in sites of adult angiogenesis by the use of soluble EphB4 [17, 18]. In addition, monoclonal inhibitory antibodies and peptides, blocking EphB4-ephrinB2 interaction have been developed to study the role of EphB4/ephbrinB2 signaling [19-21]. Further tools which have been developed in the context of EphB4/ephrinB2 signaling include engineered mouse models [3, 4, 22, 23], soluble receptors $[5,17,24]$ and peptides blocking ligand receptor interaction $[19,20]$.

Small molecule inhibitors of the EphB4 kinase have been described recently by others with different degree of specificity against other kinases [25-28]. So far, no efficacy data from in vivo studies for these compounds have been reported. In our studies we noticed, that soluble EphB4 receptor inhibits angiogenesis in a VEGF driven in vivo model, which has been used to characterize small molecule inhibitors of the VEGFR2 kinase [29]. Therefore, we tested whether the selective inhibitor of the EphB4 kinase NVPBHG712 would mimic the effect of soluble EphB4 in this VEGF driven angiogenesis model. To our knowledge, this is the first report demonstrating that a selective small molecule kinase inhibitor of the EphB4 kinase is sufficient to inhibit VEGF driven angiogenesis in vivo.

\section{Methods}

\section{Synthesis of NVP-BHG712}

Synthesis of NVP-BHG712 was performed in the laboratories of Novartis Institutes for Biomedical Research and has been described in the patent application WO2007/ 062805 [30].

In vitro kinase assays

All in vitro kinase assays were performed with recombinant purified kinases either purchased from external vendors or produced in house. To estimate kinase activity both, TR-FRET-based LanthaScreen ${ }^{\mathrm{TM}}$ and Caliper mobility shift were used. The assays have been described previously $[31,32]$.

In brief, the LanthaScreen ${ }^{\mathrm{TM}}$ assay technology is based on the discrimination between the unphosphorylated substrate and the phosphorylated product by a phospho-specific antibody, binding only to the phosphorylated version of the substrate. Both, antibody and substrate, carry fluorescent labels and the close proximity of the labels in the formed complex allows the measurement of a fluorescence resonance energy transfer (FRET) signal. Reading of the FRET signal in a time-dependent/time-gated manner further improves the assay performance by reducing background fluorescence [33]. For dose-response measurements NVPBHG712 was pre-diluted in 90\% DMSO and $50 \mathrm{~nL}$ of compound solutions were dispensed directly into the empty assay plate using a HummingBird nanodispenser (Zinsser Analytic). The kinase reactions were started by addition of $4.5 \mu \mathrm{L}$ ATP solution $(4 \mu \mathrm{M}$ ATP, $20 \mathrm{mM}$ Tris/HCL, $1 \mathrm{mM}$ DTT, $0.03 \%$ Tween $20,0.01 \mathrm{mM} \mathrm{Na} \mathrm{NO}_{4}$ ) and $4.5 \mu \mathrm{L}$ enzyme/substrate mix (100 nM fluorescein poly-GAT; Invitrogen), $0.5 \%$ bovine serum albumin, $20 \mathrm{mM}$ Tris/ HCL, $1 \mathrm{mM}$ DTT, $0.03 \%$ Tween20, $0.01 \mathrm{mM} \mathrm{Na}_{3} \mathrm{VO}_{4}$ ). Further components of the enzyme/substrate mix were the enzymes as well as $\mathrm{MgCl}_{2} / \mathrm{MnCl}_{2}$ which were adjusted specifically to the requirements of the individual enzyme. After incubation for $60 \mathrm{~min}$ at r.t. the kinase reactions were stopped by addition of $4.5 \mu \mathrm{L}$ stop solution (50 mM EDTA 
$\mathrm{pH} 8.0,0.04 \% \mathrm{NP}-40,20 \mathrm{mM}$ Tris/ $\mathrm{HCl} \mathrm{pH}$ 7.4) followed by $4.5 \mu \mathrm{L}$ of detection $\operatorname{mix}(1.72 \mu \mathrm{g} / \mathrm{mL}$ Tb-PY20 antibody; Invitrogen), $1 \%$ bovine serum albumin, $20 \mathrm{mM}$ Tris/ $\mathrm{HCl}, 1 \mathrm{mM}$ DTT, $0.03 \%$ Tween20, $0.01 \mathrm{mM} \mathrm{Na}_{3} \mathrm{VO}_{4}$ ). After incubation for $45 \mathrm{~min}$ at r.t. plates were analyzed in a BMG PHERAstar plate reader (BMG Labtech).

In the Caliper mobility shift assays kinase reactions were analyzed by microfluidic capillary electrophoresis. The transfer of phosphate from ATP to a short peptide by a kinase causes a change in the net-charge of the peptide by -2 . The charge difference between the unphosphorylated and phosphorylated entities of the peptide can be separated in an electrical field. Using peptides attached with a fluorescent label allows detection and quantification of both forms and hence the calculation of the reaction turnover. For doseresponse measurements NVP-BHG712 was pre-diluted in $90 \%$ DMSO and $50 \mathrm{~nL}$ aliquots of solution were dispensed directly into the empty assay plate using a HummingBird nanodispenser (Zinsser Analytic). The kinase reactions were started by addition of $4.5 \mu \mathrm{L}$ substrate mix consisting of ATP and peptide substrate in assay buffer (50 mM HEPES pH 7.5, $0.02 \%$ bovine serum albumin, $1 \mathrm{mM}$ DTT, $0.02 \%$ Tween 20 , $0.01 \mathrm{mM} \mathrm{Na} \mathrm{VO}_{4}, 10 \mathrm{mM}$ beta-glycerophosphate) and $4.5 \mu \mathrm{L}$ enzyme solution in assay buffer. The peptide concentration was $2 \mu \mathrm{M}$ in the assays. Concentrations for the enzyme, as well as for $\mathrm{MgCl}_{2}$ and $\mathrm{MnCl}_{2}$ were adjusted specifically to the requirements of the individual enzyme. ATP concentrations were adjusted to the $K_{\mathrm{M}}$ values of the specific enzyme. After incubation for $60 \mathrm{~min}$ at $30^{\circ} \mathrm{C}$ the kinase reactions were stopped by addition of $16 \mu \mathrm{L}$ stop solution (100 mM HEPES pH 7.5, 5\% DMSO, 0.1\% coating reagent (Caliper Lifescience) 10 mM EDTA pH 8.0, 0.015\% BRIJ35). Stopped kinase reactions were analyzed in a LC3000 reader (Caliper Lifescience).

\section{Autophosphorylation of transient expressed Eph receptors}

Human cDNAs encoding the full length human EphA2, EphA3, EphB2, EphB3 and EphB4 sequence were cloned into pCDNA3.1 expression plasmids (Invitrogen). A C-terminal V5-tag (Invitrogen) was introduced into the cDNA of EphA1, A2, B2 and B3, the cDNA of EphB4 was C-terminal fused with a myc-epitope. For expression of the different EphRs Hek293 human embryonic kidney epithelial cells (ATTC No CRL-157) were transiently transfected using FuGENE 6 transfection reagent (Roche) following the protocol provided by the vendor. Autophosphorylation of EphRs receptors was either initiated by the addition of soluble ephrinA1-Fc (1 $\mu \mathrm{g} / \mathrm{ml}$, R\&D Systems; EphA2, EphA3) or by the addition of a mixture of soluble ephrinB1-Fc and soluble ephrinB2-Fc $(1 \mu \mathrm{g} / \mathrm{ml}$ each, R\&D Systems; EphB2, EphB3, EphB4), respectively. EphR proteins were immunoprecipated using either anti-V5-epitope or anti-myc-epitope antibodies and analyzed by western using the mab 4G10 anti-phospho-tyrosine antibody.

\section{Cell based phospho-RTK-ELISA}

Activity of cellular receptor tyrosine kinase activity was assessed by different capture ELISAs. The assays for VEGFR2, IGF1R and InsR have been described elsewhere [29, 31].

For the EphB4 cell based ELISA a stable clone of transfected A375 cells has been generated which overexpress human full length EphB4. Cells were seeded in 96 well plates for $24 \mathrm{~h}$, starved over night in medium lacking FCS but containing $0.1 \%$ BSA and stimulated with soluble ephrinB2-Fc (1 $\mu \mathrm{g} / \mathrm{ml} / \mathrm{R} \& \mathrm{D}$ Systems $)$ for $20 \mathrm{~min}$ to enhance EphB4 autophosphorylation. Cells were lysed in RIPA buffer and captured on Nunc MaxiSorb plates which had been coated with soluble ephrinB2-Fc (100 ng/well). Detection of phosphorylated EphB4 was done by the use of mab PY20 (anti-phospho-tyrosine antibody) coupled to alkaline phosphatase (ZYMED, Cat Nr 03-7722) diluted 1:5000. After washing $(3 \times$ with PBS) bound PY20 was quantified by the addition of $0.1 \mathrm{ml}$ substrate buffer and measuring the OD at $405 \mathrm{~nm}$ after about $30 \mathrm{~min}$ until yellow color appeared.

\section{Pharmacokinetic analysis}

Quantification of NVP-BHG712 in plasma and tissue was performed using HPLC/UV. At the allotted times, mice (4 at each time) were anesthetized by exposure to approximately $3 \% \mathrm{v} / \mathrm{v}$ isofluorane in medical oxygen and, after sampling, killed without recovering from anesthetic. Blood samples were drawn from the vena cava into heparinized Eppendorf tubes $(30 \mathrm{IU} / \mathrm{mL})$ and the plasma prepared from the blood by centrifugation $(10,000 \times \mathrm{g}, 5 \mathrm{~min}$.) The tissues were excised weighed and rapidly frozen in liquid nitrogen. Plasma and tissue samples were stored frozen at $-70^{\circ} \mathrm{C}$ until analysis. Frozen tissues were minced, then homogenized in an equal volume of ice-cold phosphate buffered saline (PBS, Sigma P4417) using a Polytron homogenizer (TP18-10, IKA, Staufen, Germany) keeping the material cold during the homogenization. Proteins in plasma or tissue were precipitated by the addition of an equal volume of acetonitrile. After 20-30 min at room temperature the protein precipitate was removed by centrifugation $(10,000 \mathrm{~g}, 5 \mathrm{~min}$.). The supernatant was analyzed immediately by reversed phase HPLC/UV.

Studies concerning pharmacokinetic analysis described in this report were performed according to animal experimentation license no. 1766, approved by the Basel Stadt Authorities. 
Analysis of phosphorylated EphB4 receptor in lung tissue

For per oral administration to mice the research formulation 1-Methyl-2-pyrrolidone (NMP) and polyethylene glycol 300 (PEG300) was used. The free bases were formulated by first dissolving the substances in NMP and then diluting with PEG300 to a final concentration of $10 \% \mathrm{v} / \mathrm{v}$ NMP and $90 \% \mathrm{v} / \mathrm{v}$ PEG300, producing clear solutions of the compounds. The final concentration was $5 \mathrm{mg} / \mathrm{mL}$ to deliver $50 \mathrm{mg} / \mathrm{kg}$. Administration volume was $10 \mathrm{~mL} / \mathrm{kg}$ body weight.

Isolated lungs were immediately snap frozen in liquid nitrogen and kept at $-80^{\circ} \mathrm{C}$ until further analysis. To immuno-precipitate EphB4 from lung tissue, one $\mathrm{ml}$ of ice cold lysis buffer was added to one frozen lung lobe and tissue was with a polytron homogenizer for $20 \mathrm{~s}$. The homogenate was kept on ice for $1 \mathrm{~h}$ to ensure cell lysis and cellular debris were removed by centrifugation at $2000 \mathrm{rpm}$ for $15 \mathrm{~min}$. Supernatants were mixed with an equal volume of $2 \mathrm{mM}$ vanadate in $\mathrm{PBS}$ and filtered through a low protein binding glass fiber filter. To remove proteins which unspecifically bind to protein A or protein $\mathrm{G}, 0.05 \mathrm{ml}$ of protein $\mathrm{A} / \mathrm{G}$ bead slurry (PIERCE) was added and lysates were incubated for $1-2 \mathrm{~h}$ on a rotating wheel. Next beads were removed by centrifugation ( $3 \mathrm{~min}$ at $5000 \mathrm{rpm}$ ) and supernatants were transferred to fresh tubes. Protein content was estimated using the BCA protein assay kit (PIERCE) following the instructions of the supplier. For immuno-precipitation of EphB4 $0.5 \mathrm{mg}$ of lung protein was used. $0.5 \mu \mathrm{g}$ of the corresponding antibody (goat anti-mouse EphB4 antibody; R\&D) was added and incubated on a rotating wheel for $2 \mathrm{~h}$ or over night. Next $10 \mu \mathrm{l}$ of protein $\mathrm{A} / \mathrm{G}$ beads were added and incubated for another hour on a rotating wheel. Protein A/G beads were span down and washed twice with ice cold PBS supplemented with $0.5 \mathrm{mM}$ vanadate. PBS was carefully removed. $25 \mu \mathrm{l}$ of SDS sample buffer was added, the samples were heated for $3 \mathrm{~min}$ at $95^{\circ} \mathrm{C}$ and proteins were separated on $7.5 \%$ SDS-PAGE.

In vivo growth factor-induced angiogenesis model

VEGF-mediated angiogenesis in vivo was induced in a growth factor implant model in mice as described previously [29, 34, 35]. In this model VEGF is delivered from an agar chamber which is implanted sub-cutaniously. VEGF increases dose dependently the amount of newly formed tissue around the chamber. In previous studies we have shown that the amount of adherent, vascularized tissue growing around the chambers and the amount of blood vessels in this newly formed tissue assessed by either hemoglobin (converted to equivalents of blood), and Tie-2

content (number of endothelial cells and therefore vessel density) is blocked by antibodies that specifically neutralize VEGF or by VEGFR tyrosine kinase inhibitors.

Studies concerning the VEGF driven angiogenesis model described in this report were performed according to animal experimentation license no. 1325, approved by the Basel Stadt Authorities.

\section{Results}

Kinase inhibitor profile of NVP-BHG712

Design of NVP-BHG712 was supported by molecular modeling of the kinase domain of EphB4 and further optimized using structure-activity-relationship data based on inhibition of EphB4 autophosphorylation in a cellular assay. For this a capture ELISA has been developed utilizing stable transfected A375 melanoma cells overexpressing human full length EphB4 receptor fused to a myc-epitope at the C-terminal end of the protein. A375 melanoma cells were chosen, because endogenous levels of EphB4 are nearly undetectable and expression of either soluble EphB4 or full length EphB4 did not interfere with cell growth in previous experiments [17]. Selectivity of NVP-BHG712 was demonstrated in a panel of more than 40 biochemical in vitro kinase assays as well as three other cell based ELISA assays for RTK autophosphorylation (Fig. 1). In the biochemical assay panel, only c-raf, c-src and c-abl were identified as potential off-targets. In the cell based ELISA assays for phosphorylated RTKs, marginal

NVP-BHG712
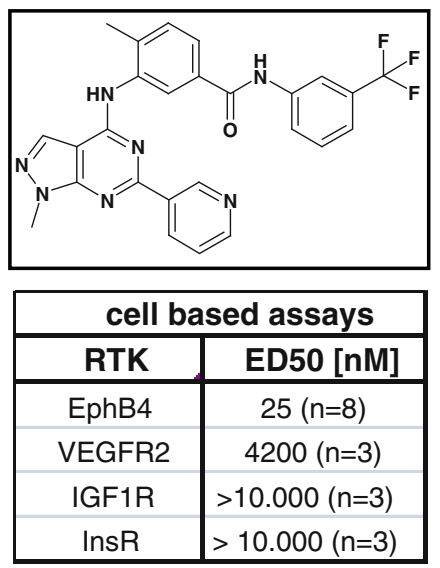

\begin{tabular}{|c|c|}
\hline \multicolumn{2}{|c|}{ in vitro kinase assay } \\
\hline kinase & IC50 (nM) \\
\hline c-raf & 395 \\
\hline C-src & 1266 \\
c-Abl & 1667 \\
\hline Tie2 & $>10000$ \\
\hline Axl & $>10000$ \\
\hline Her1 & $>10000$ \\
\hline PKA & $>10000$ \\
CDK1 & $>10000$ \\
\hline PKB & $>10000$ \\
\hline PDK1 & $>10000$ \\
\hline FGFR3 & $>10000$ \\
\hline C-Met & $>10000$ \\
\hline
\end{tabular}

Fig. 1 Structure and selectivity profile of NVP-BHG712. NVPBHG712 has been optimized as a specific inhibitor of the EphB4 kinase in cell based assays measuring different receptor tyrosine kinases (RTKs) as described in the material and method chapter. The compound has been further profiled in various biochemical kinase assays as indicated 
inhibition of VEGFR2 was observed (ED50 = $4200 \mathrm{nM})$ while ED50 for EphB4 inhibition in this format was estimated be $25 \mathrm{nM}$, demonstrating that NVP-BHG712 clearly discriminates between VEGFR and EphB4 inhibition.

NVP-BHG712 is highly potent in EphR autophosphorylation cell based assays

To demonstrate the inhibitory activity of NVP-BHG712 in cell based assay, we also transiently transfected different EphRs in Hek293 cells. For analysis of EphR autophosphorylation we immuno-precipitated the different receptor proteins and analyzed tyrosine phosphorylation of the receptors with generic anti-phospho-tyrosine antibodies. Basal levels of EphR autophosphorylation was observed for all the EphRs which have been transfected, but was further enhanced by the addition of the appropriate ligand (Fig. 2). Addition of NVP-BHG712 dose dependently inhibited autophosphorylation of the EphRs, showing some preference for EphB4 followed by inhibition of EphB2, EphA2, EphB3 and EphA3. Half maximal inhibition of EphB4 autophosphorylation was in the low nanomolar range and confirmed data obtained by the ELISA using stable transfected A375 (see Fig. 1).

NVP-BHG712 has excellent pharmacokinetic properties and inhibits EphB4 autophosphorylation in lung tissue

To explore the use of NVP-BHG712 in animal studies we performed pharmacokinetic/pharmacodynamic studies in

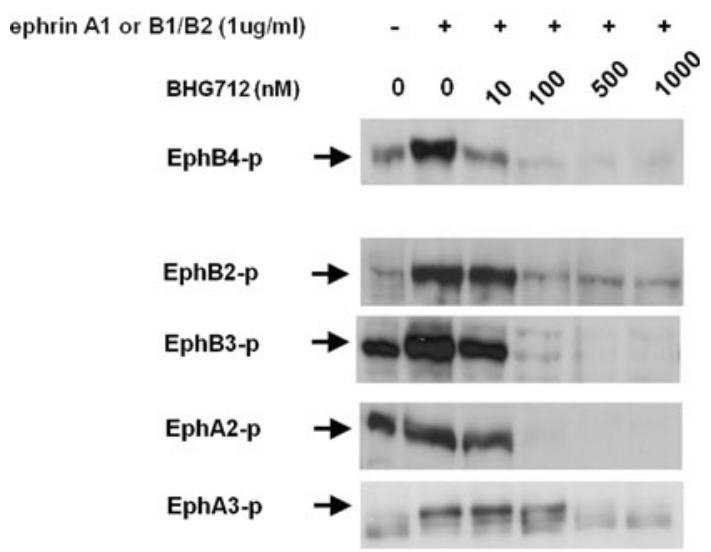

Fig. 2 NVP-BHG712 inhibits multiple Eph receptor kinases in cell based assays. Different EphR full length cDNAs have been transiently expressed in Hek293 cells. EphR autophosphorylation has been initiated by stimulating cells for $30 \mathrm{~min}$ with either $1 \mu \mathrm{g} / \mathrm{ml}$ ephrinA1-Fc (EphA2, EphA3) or a combination of $1 \mu \mathrm{g} / \mathrm{ml}$ ephrinB1-Fc and $1 \mu \mathrm{g} / \mathrm{ml}$ ephrinB2-Fc. NVPBHG712 was added $1 \mathrm{~h}$ prior cell stimulation and autophosphorylation was monitored by immuno-precipitation of EphR protein followed by western analysis using anti-phospho-tyrosine antibodies mouse lung tissue. Oral administration of NVP-BHG712 showed a long lasting exposure of parent compound in plasma as well as in different tissues (Fig. 3b). Concentrations around $10 \mu \mathrm{M}$ were observed in lung and liver tissue for up to $8 \mathrm{~h}$ upon administration of $50 \mathrm{mg} / \mathrm{kg}$ of NVP-BHG712, exceeding far the $\mathrm{IC}_{50}$ for $\mathrm{EphB} 4$ inhibition. EphB4 is expressed in many tissues including lung and liver and co-expression of EphB4 and ephrinB2 has been observed in lung tissue on RNA as well as on protein levels (data not shown). Thus it is not surprising to detect autophosphorylated EphB4 receptors in lung tissue (Fig. 3a), although a physiological role for EphB4/ephrinB2 signaling in lung tissue has not be described so far. As expected, NVP-BHG712 inhibited EphB4 autophosphorylation in lung tissue. Parallel analysis of phospholevels of EphB4 and tissue concentration of NVP-BHG712
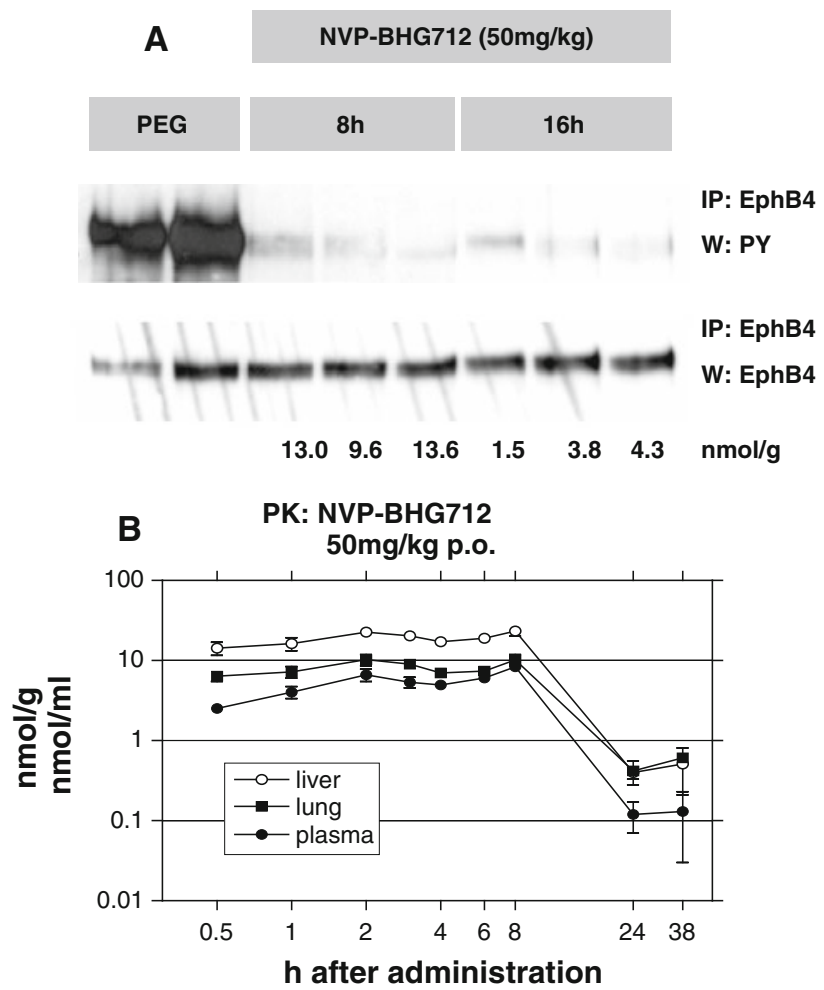

Fig. 3 NVP-BHG712 inhibits endogenous EphB4 autophosphorylation in lung tissue of mice and has micromolar exposure in plasma and tissues. NVP-BHG712 has been dosed orally in mice $(50 \mathrm{mg} / \mathrm{kg})$. Mice have been sacrificed at time points after oral compound administration as indicated. a To monitor NVP-BHG712 concentration and EphB4 autophosphorylation in lung tissue, one lung lobe were lysed for western analysis and the other lung lobe was used for pharmacokinetic analysis. EphB4 protein was immuno-precipitated from lung tissue lysates and analyzed by western using anti-phosphotyrosine antibodies. Membranes were stripped and reprobed with a specific anti-EphB4 antibody to ensure equal protein loading. Corresponding NVP-BHG712 concentrations are indicated below each lane. b NVP-BHG712 concentrations in plasma (filled circle), lung tissue (filled square) and liver tissue (open circle) were analyzed by HPLC-UV as described in the material and method chapter 
in the lung revealed that approximately $1 \mathrm{nmol} / \mathrm{g}$ (equivalent to $1 \mu \mathrm{M}$ ) was sufficient to have a pronounced inhibitory effect on EphB4 phosphorylation (Fig. 3a). From these analyses we concluded that a once daily oral dosing of $50 \mathrm{mg} / \mathrm{kg}$ NVP-BHG712 results in a long lasting inhibition of EphB4 kinase activity in mice.

Inhibition of EphB4 forward signaling inhibits VEGF driven angiogenesis

The role of EphB4/ephrinB2 signaling in angiogenesis of the developing embryo as well as in tumor growth has been demonstrated by many groups $[4,11,17,36]$. Soluble EphB4 receptor protein has been used in a variety of studies to inhibit EphB4/ephrinB2 signaling [17, 18, 24]. Recombinant soluble EphB4 protein potentially has different effects on EphB4/ephrinB2 signaling depending on whether it is expressed as a fusion protein with the Fc-part of IgG1 or not. Fc-fused soluble receptors are generally used to facilitate protein purification and to enhance protein stability in plasma when applied in vivo. In addition, Fcfusion proteins form stable dimers due to disulfide bonding of the Fc part of the molecule. Thus, soluble EphB4-Fc should prevent ephrinB2 from binding to the native receptors and thereby inhibit EphB4 activation, but it still might force ephrinB2 protein to dimerize and potentially elicit some agonistic effects on ephrinB2 reverse signaling.

In order to study the role of EphB4 forward signaling in angiogenesis we applied soluble EphB4-Fc as well NVPBHG712 in an in vivo model of VEGF driven angiogenesis, which we had used before to profile other kinase inhibitors [29, 35]. In this model, VEGF is released from a Teflon chamber filled with agar mixed with VEGF. Within 4 days newly formed tissue is observed adherent to the chamber. The amount of tissue (measured as tissue weight) as well as the vascular density within this newly formed tissue (as measured by either hemoglobin or Tie2-levels, a marker of endothelial cells) is dose dependently increased by VEGF (Fig. 4). Furthermore, tissue formation and vascularisation around the Teflon chamber is significantly inhibited by administration of either inhibitory antibodies against VEGF or specific kinase inhibitors of the VEGFR [29]. Addition of soluble EphB4-Fc together with VEGF significantly inhibited tissue formation as well as tissue vascularisation (Fig. 4). Since sEphB4-Fc is an antagonist of EphB4 forward signaling but might still act agonistic on ephrinB2 reverse signaling, we speculated, that inhibition of EphB4 forward signaling is sufficient to block VEGF driven angiogenesis. This assumption was confirmed by the use of NVP-BHG712. NVP-BHG712 inhibited dose dependently VEGF stimulated tissue formation and vascularization in this model. Already at doses of daily $3 \mathrm{mg} / \mathrm{kg}$ p.o administration we observed significant inhibition, and daily
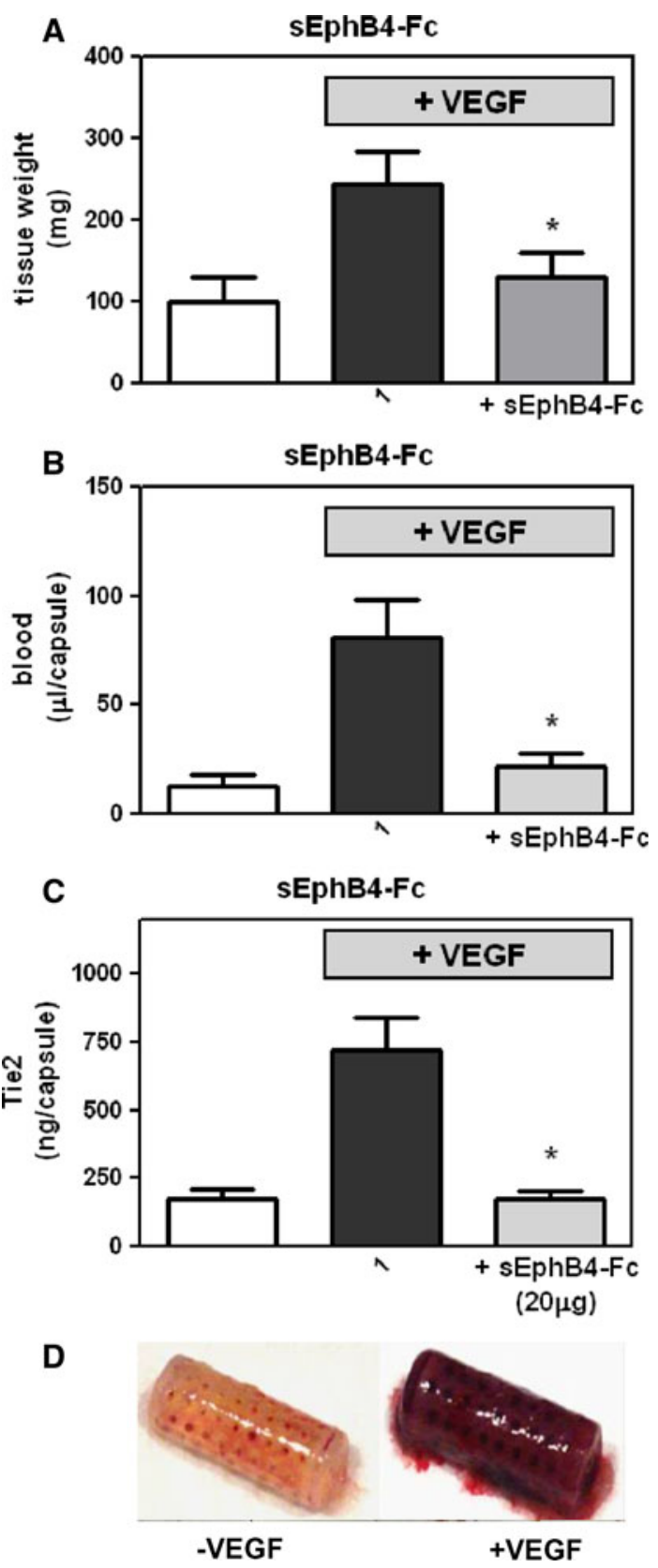

Fig. 4 Soluble EphB4-Fc protein inhibits VEGF driven tissue growth and angiogenesis. Porous Teflon chambers were either filled with $0.5 \mathrm{ml}$ of $0.8 \%(\mathrm{w} / \mathrm{v})$ buffered agar (white bars), or $0.5 \mathrm{ml}$ of $0.8 \%$ agar containing $2 \mu \mathrm{g}$ recombinant purified VEGF (black bars), or $0.5 \%$ agar containing a mixture of $2 \mu \mathrm{g}$ recombinant purified VEGF and $20 \mu \mathrm{g}$ recombinant purified sEphB4-Fc (grey bars). Chambers were implanted sub-cutaneously in the flank of FVB mice. The responses to VEGF and VEGF in combination with $\mathrm{SEphB} 4-\mathrm{Fc}$ were analyzed 4 days after implantation by measuring tissue weight (a), blood content (b) and Tie-2 levels (c). Typical chamber explants of buffer and VEGF controls after 4 days are shown (d). Values are mean \pm SEM. $* p<0.05$, statistical significance of inhibition, MannWhitney Rank Sum Test ( $n=6$ per group per experiment)

administration of $10 \mathrm{mg} / \mathrm{kg} / \mathrm{kg}$ p.o. was sufficient to reverse VEGF enhanced tissue formation and vessel growth (Fig. 5). From our previous pharmacokinetic 
A
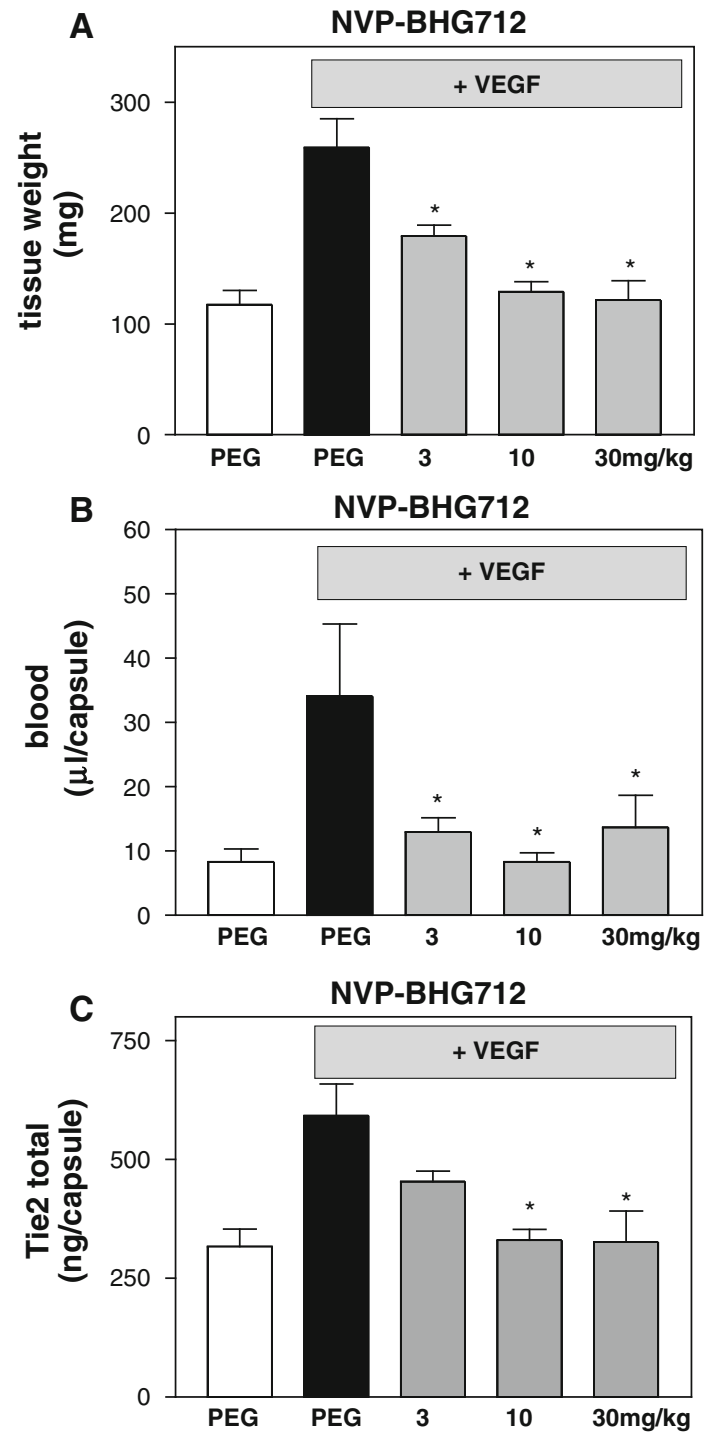

Fig. 5 NVP-BHG712 inhibits VEGF driven tissue growth and angiogenesis. Porous Teflon chambers were either filled with $0.5 \mathrm{ml}$ of $0.8 \%(\mathrm{w} / \mathrm{v})$ buffered agar (white bars), or $0.5 \mathrm{ml}$ of $0.8 \%$ agar containing $2 \mu \mathrm{g}$ recombinant purified VEGF (black bars). Mice carrying chambers containing VEGF were treated orally once daily with NVP-BGH712 (3, 10 and $30 \mathrm{mg} / \mathrm{kg} /$ day p.o.; grey bars). The responses to VEGF and VEGF together with daily oral dosing of NVP-BHG712 were analyzed 4 days after implantation by measuring tissue weight (a), blood content (b) and Tie-2 levels (c). Values are mean \pm SEM. ${ }^{*} p<0.05$, statistical significance of inhibition, MannWhitney Rank Sum Test ( $n=6$ per group per experiment)

studies we can conclude, that tissue as well as plasma levels of NVP-BHG712 do not exceed $1 \mu \mathrm{M}$ under these conditions and thus are far to low to have any inhibitory effects on VEGFR2 (see Fig. 1). The congruent results by either inhibiting EphB4 forward signaling using soluble EphB4-Fc as well as the inhibitory effects of NVPBHG712 further strengthen the finding that EphB4 receptor forward signaling indeed participates in VEGF driven angiogenesis.

\section{Discussion}

NVP-BHG712 was synthesized based on rational design and further optimization led to a potent and selective inhibitor of the EphB4 receptor tyrosine kinase, as demonstrated in cell based assays. In a panel of more than 40 in vitro kinase assays, NVP-BHG712 showed excellent selectivity. Only c-raf, c-src and c-abl showed moderate inhibition as judged from our biochemical assays. In cell based assays ED50 for inhibition of EphB4 autophosphorylation was found to be $25 \mathrm{nM}$ and thereby be roughly 200 fold more potent on EphB4 than on VEGFR2. Inhibitors of the EphB4 kinase have been described also by others [25-28] but for none of them modulation of EphB4 activity in vivo has been reported. Although there exist several reports demonstrating the involvement of EphB4/ephrinB2 signaling in vessel growth and tumor angiogenesis, evidence is lacking, that a small molecule inhibitor of the EphB4 kinase is sufficient to inhibit angiogenesis. Most of the tools which have been applied in previous studies do not allow discrimination of inhibition of EphB4 forward versus ephrinB2 reverse signaling. Furthermore, targeted deletion of the cytoplasmic domain of ephrinB2 in mice as well as conditional knock out of ephrinB2 suggested an involvement of ephrin reverse signaling in embryonic vessel development $[22,37]$. Here we describe for the first time that a small molecule inhibitor of the EphB4 kinase inhibits VEGF driven angiogenesis in vivo. From our cell based assays and pharmacokinetic/pharmacodynamic analysis we can rule out that inhibition of VEGFR kinase contributes to the observed in vivo effects of NVP-BHG712. Nevertheless, although NVP-BHG712 shows selectivity against many kinases, it can not discriminate among different Eph receptor kinases. Complicating matters, EphB4 is not the only Eph receptor expressed in the endothelium and adjacent pericytes. EphrinA1 as well as ephrinB1 and EphA2, EphB2, EphB3 have been reported to be expressed either on the endothelium or adjacent pericytes (for review see [38-40]). Targeted deletion of EphA2, soluble EphA2 receptors, as well as double transgenic mice lacking EphB2 and EphB3 result in inhibition or defective angiogenesis $[38,41-43]$. Thus we can not rule out, that inhibition of other Eph receptor kinases contribute to inhibition of VEGF driven angiogenesis. However, our data presented here strongly suggest a close cross talk between EphR and VEGFR signaling, and that both signaling pathways are needed for a coordinated vessel formation. In endothelial cells, activation of EphR signaling inhibits VEGF and Angiopoietin induced MAPK activation, presumably due to activation of the RasGap protein by activated EphRs [44].While this manuscript was in preparation two independent studies demonstrated that ephrinB2 regulates internalization and signaling of VEGFR2 and VEGFR3 and 
VEGF induced embryonic angiogenesis [45, 46]. These studies demonstrated the involvement of ephrinB2 in filapodia formation of the endothelial tip cell in sprouting vessels which was dependent on the presence of the c-terminal PDZ domain of ephrinB2 [45]. Since we have used sEphB4-Fc as a tool we can not completely rule out that activation of ephrinB2 contributes to the observed phenotype. Since NVP-BHG712 pheno-copied the effects of sEphB4-Fc in our model we assume that inhibition of EphB4 forward signaling is the predominant cause of inhibition of angiogenesis at least in the model described here. In summary our data demonstrate for the first time, that specific inhibitors of EphR kinases are effective inhibitors of VEGF driven angiogenesis in vivo and thereby open a new potential avenue to block angiogenesis in diseases such as cancer or inflammatory diseases.

Disclosure Georg Martiny-Baron, Philipp Holzer, Eric Billy, Christian Schnell, Joseph Brueggen, Mireille Ferretti, Niko Schmiedeberg, Pascal Furet and Patricia Imbach are employees of Novartis AG, Switzerland. Jeanette Wood is a former employee of Novartis.

Open Access This article is distributed under the terms of the Creative Commons Attribution Noncommercial License which permits any noncommercial use, distribution, and reproduction in any medium, provided the original author(s) and source are credited.

\section{References}

1. Yancopoulos GD, Davis S, Gale NW, Rudge JS, Wiegand SJ, Holash J (2000) Vascular-specific growth factors and blood vessel formation. Nature 407:242-248

2. Pasquale EB (2008) Eph-ephrin bidirectional signaling in physiology and disease. Cell 133:38-52

3. Gerety SS, Wang HU, Chen ZF, Anderson DJ (1999) Symmetrical mutant phenotypes of the receptor EphB4 and its specific transmembrane ligand ephrin-B2 in cardiovascular development. Mol Cell 4:403-414

4. Wang HU, Chen ZF, Anderson DJ (1998) Molecular distinction and angiogenic interaction between embryonic arteries and veins revealed by ephrin-B2 and its receptor Eph-B4. Cell 93:741-753

5. Kumar SR, Singh J, Xia G, Krasnoperov V, Hassanieh L, Ley EJ, Scehnet J, Kumar NG, Hawes D, Press MF, Weaver FA, Gill PS (2006) Receptor tyrosine kinase EphB4 is a survival factor in breast cancer. Am J Pathol 169:279-293

6. Stephenson SA, Slomka S, Douglas EL, Hewett PJ, Hardingham JE (2001) Receptor protein tyrosine kinase EphB4 is up-regulated in colon cancer. BMC Mol Biol 2:15

7. Liu W, Ahmad SA, Jung YD, Reinmuth N, Fan F, Bucana CD, Ellis LM (2002) Coexpression of ephrin-Bs and their receptors in colon carcinoma. Cancer 94:934-939

8. Berclaz G, Karamitopoulou E, Mazzucchelli L, Rohrbach V, Dreher E, Ziemiecki A, Andres AC (2003) Activation of the receptor protein tyrosine kinase EphB4 in endometrial hyperplasia and endometrial carcinoma. Ann Oncol 14:220-226

9. Lee YC, Perren JR, Douglas EL, Raynor MP, Bartley MA, Bardy PG, Stephenson SA (2005) Investigation of the expression of the EphB4 receptor tyrosine kinase in prostate carcinoma. BMC Cancer 5:119
10. Castellano G, Reid JF, Alberti P, Carcangiu ML, Tomassetti A, Canevari S (2006) New potential ligand-receptor signaling loops in ovarian cancer identified in multiple gene expression studies. Cancer Res 66:10709-10719

11. Noren NK, Lu M, Freeman AL, Koolpe M, Pasquale EB (2004) Interplay between EphB4 on tumor cells and vascular ephrin-B2 regulates tumor growth. Proc Natl Acad Sci U S A 101: 5583-5588

12. Batlle E, Bacani J, Begthel H, Jonkheer S, Gregorieff A, van de Born M, Malats N, Sancho E, Boon E, Pawson T, Gallinger S, Pals S, Clevers H (2005) EphB receptor activity suppresses colorectal cancer progression. Nature 435:1126-1130

13. Noren NK, Foos G, Hauser CA, Pasquale EB (2006) The EphB4 receptor suppresses breast cancer cell tumorigenicity through an Abl-Crk pathway. Nat Cell Biol 8:815-825

14. Dopeso H, Mateo-Lozano S, Mazzolini R, Rodrigues P, LagaresTena L, Ceron J, Romero J, Esteves M, Landolfi S, HernandezLosa J, Castano J, Wilson AJ, Ramon y Cajal S, Mariadason JM, Schwartz S Jr, Arango D (2009) The receptor tyrosine kinase EPHB4 has tumor suppressor activities in intestinal tumorigenesis. Cancer Res 69:7430-7438

15. Xia G, Kumar SR, Masood R, Zhu S, Reddy R, Krasnoperov V, Quinn DI, Henshall SM, Sutherland RL, Pinski JK, Daneshmand S, Buscarini M, Stein JP, Zhong C, Broek D, Roy-Burman P, Gill PS (2005) EphB4 expression and biological significance in prostate cancer. Cancer Res 65:4623-4632

16. Noren NK, Pasquale EB (2007) Paradoxes of the EphB4 receptor in cancer. Cancer Res 67:3994-3997

17. Martiny-Baron G, Korff T, Schaffner F, Esser N, Eggstein S, Marme D, Augustin HG (2004) Inhibition of tumor growth and angiogenesis by soluble EphB4. Neoplasia 6:248-257

18. He S, Ding Y, Zhou J, Krasnoperov V, Zozulya S, Kumar SR, Ryan SJ, Gill PS, Hinton DR (2005) Soluble EphB4 regulates choroidal endothelial cell function and inhibits laser-induced choroidal neovascularization. Invest Ophthalmol Vis Sci 46:4772-4779

19. Koolpe M, Burgess R, Dail M, Pasquale EB (2005) EphB receptor-binding peptides identified by phage display enable design of an antagonist with ephrin-like affinity. J Biol Chem 280:17301-17311

20. Chrencik JE, Brooun A, Recht MI, Kraus ML, Koolpe M, Kolatkar AR, Bruce RH, Martiny-Baron G, Widmer H, Pasquale EB, Kuhn P (2006) Structure and thermodynamic characterization of the EphB4/Ephrin-B2 antagonist peptide complex reveals the determinants for receptor specificity. Structure 14:321-330

21. Krasnoperov V, Kumar SR, Ley E, Li X, Scehnet J, Liu R, Zozulya S, Gill PS (2010) Novel EphB4 Monoclonal Antibodies Modulate Angiogenesis and Inhibit Tumor Growth. Am J Pathol

22. Adams RH, Diella F, Hennig S, Helmbacher F, Deutsch U, Klein R (2001) The cytoplasmic domain of the ligand ephrinB2 is required for vascular morphogenesis but not cranial neural crest migration. Cell 104:57-69

23. Andres AC, Munarini N, Djonov V, Bruneau S, Zuercher G, Loercher S, Rohrbach V, Ziemiecki A (2003) EphB4 receptor tyrosine kinase transgenic mice develop glomerulopathies reminiscent of aglomerular vascular shunts. Mech Dev 120:511-516

24. Kertesz N, Krasnoperov V, Reddy R, Leshanski L, Kumar SR, Zozulya S, Gill PS (2006) The soluble extracellular domain of EphB4 (sEphB4) antagonizes EphB4-EphrinB2 interaction, modulates angiogenesis, and inhibits tumor growth. Blood 107:2330-2338

25. Bardelle C, Coleman T, Cross D, Davenport S, Kettle JG, Ko EJ, Leach AG, Mortlock A, Read J, Roberts NJ, Robins P, Williams EJ (2008) Inhibitors of the tyrosine kinase EphB4. Part 2: structure-based discovery and optimisation of 3, 5-bis substituted anilinopyrimidines. Bioorg Med Chem Lett 18:5717-5721 
26. Bardelle C, Cross D, Davenport S, Kettle JG, Ko EJ, Leach AG, Mortlock A, Read J, Roberts NJ, Robins P, Williams EJ (2008) Inhibitors of the tyrosine kinase EphB4. Part 1: Structure-based design and optimization of a series of 2, 4-bis-anilinopyrimidines. Bioorg Med Chem Lett 18:2776-2780

27. Mitchell SA, Danca MD, Blomgren PA, Darrow JW, Currie KS, Kropf JE, Lee SH, Gallion SL, Xiong JM, Pippin DA, DeSimone RW, Brittelli DR, Eustice DC, Bourret A, Hill-Drzewi M, Maciejewski PM, Elkin LL (2009) Imidazo[1, 2-a]pyrazine diaryl ureas: inhibitors of the receptor tyrosine kinase EphB4. Bioorg Med Chem Lett 19:6991-6995

28. Lafleur K, Huang D, Zhou T, Caflisch A, Nevado C (2009) Structure-based optimization of potent and selective inhibitors of the tyrosine kinase erythropoietin producing human hepatocellular carcinoma receptor B4 (EphB4). J Med Chem 52:6433-6446

29. Wood JM, Bold G, Buchdunger E, Cozens R, Ferrari S, Frei J, Hofmann F, Mestan J, Mett H, O'Reilly T, Persohn E, Rosel J, Schnell C, Stover D, Theuer A, Towbin H, Wenger F, WoodsCook K, Menrad A, Siemeister G, Schirner M, Thierauch KH, Schneider MR, Drevs J, Martiny-Baron G, Totzke F (2000) PTK787/ZK 222584, a novel and potent inhibitor of vascular endothelial growth factor receptor tyrosine kinases, impairs vascular endothelial growth factor-induced responses and tumor growth after oral administration. Cancer Res 60:2178-2189

30. Holzer P, Imbach P, Furet P, Schmiedeberg N (2007) 3-(Substituted Amino)-Pyrazolo[3,4-d]Pyrimidines as EphB and VEGFR2 Kinase Inhibitors. In: W.I.P. Organization (ed) WO 2007/062805 A1

31. Garcia-Echeverria C, Pearson MA, Marti A, Meyer T, Mestan J, Zimmermann J, Gao J, Brueggen J, Capraro HG, Cozens R, Evans DB, Fabbro D, Furet P, Porta DG, Liebetanz J, MartinyBaron G, Ruetz S, Hofmann F (2004) In vivo antitumor activity of NVP-AEW541-A novel, potent, and selective inhibitor of the IGF-IR kinase. Cancer Cell 5:231-239

32. Manley PW, Drueckes P, Fendrich G, Furet P, Liebetanz J, Martiny-Baron G, Mestan J, Trappe J, Wartmann M, Fabbro D (2009) Extended kinase profile and properties of the protein kinase inhibitor nilotinib. Biochim Biophys Acta 1804:445-453

33. Mathis G (1995) Probing molecular interactions with homogeneous techniques based on rare earth cryptates and fluorescence energy transfer. Clin Chem 41:1391-1397

34. Weber CC, Cai H, Ehrbar M, Kubota H, Martiny-Baron G, Weber W, Djonov V, Weber E, Mallik AS, Fussenegger M, Frei K, Hubbell JA, Zisch AH (2005) Effects of protein and gene transfer of the angiopoietin-1 fibrinogen-like receptor-binding domain on endothelial and vessel organization. J Biol Chem 280:22445-22453
35. Lane HA, Wood JM, McSheehy PM, Allegrini PR, Boulay A, Brueggen J, Littlewood-Evans A, Maira SM, Martiny-Baron G, Schnell CR, Sini P, O'Reilly T (2009) mTOR inhibitor RAD001 (everolimus) has antiangiogenic/vascular properties distinct from a VEGFR tyrosine kinase inhibitor. Clin Cancer Res $15: 1612-1622$

36. Adams RH, Klein R (2000) Eph receptors and ephrin ligands. Essential mediators of vascular development. Trends Cardiovasc Med 10:183-188

37. Gerety SS, Anderson DJ (2002) Cardiovascular ephrinB2 function is essential for embryonic angiogenesis. Development 129:1397-1410

38. Adams RH, Wilkinson GA, Weiss C, Diella F, Gale NW, Deutsch U, Risau W, Klein R (1999) Roles of ephrinB ligands and EphB receptors in cardiovascular development: demarcation of arterial/ venous domains, vascular morphogenesis, and sprouting angiogenesis. Genes Dev 13:295-306

39. Cheng N, Brantley DM, Chen J (2002) The ephrins and Eph receptors in angiogenesis. Cytokine Growth Factor Rev 13:75-85

40. Kojima T, Chung TY, Chang JH, Sayegh R, Casanova FH, Azar DT (2007) Comparison of EphA receptor tyrosine kinases and ephrinA ligand expression to EphB-ephrinB in vascularized corneas. Cornea 26:569-578

41. Chen J, Hicks D, Brantley-Sieders D, Cheng N, McCollum GW, Qi-Werdich X, Penn J (2006) Inhibition of retinal neovascularization by soluble EphA2 receptor. Exp Eye Res 82:664-673

42. Brantley-Sieders DM, Fang WB, Hicks DJ, Zhuang G, Shyr Y, Chen J (2005) Impaired tumor microenvironment in EphA2deficient mice inhibits tumor angiogenesis and metastatic progression. Faseb J 19:1884-1886

43. Okazaki T, Ni A, Baluk P, Ayeni OA, Kearley J, Coyle AJ, Humbles A, McDonald DM (2009) Capillary defects and exaggerated inflammatory response in the airways of EphA2-deficient mice. Am J Pathol 174:2388-2399

44. Kim I, Ryu YS, Kwak HJ, Ahn SY, Oh JL, Yancopoulos GD, Gale NW, Koh GY (2002) EphB ligand, ephrinB2, suppresses the VEGF- and angiopoietin 1-induced Ras/mitogen-activated protein kinase pathway in venous endothelial cells. Faseb J 16:1126-1128

45. Sawamiphak S, Seidel S, Essmann CL, Wilkinson GA, Pitulescu ME, Acker T, Acker-Palmer A (2010) Ephrin-B2 regulates VEGFR2 function in developmental and tumour angiogenesis. Nature 465:487-491

46. Wang Y, Nakayama M, Pitulescu ME, Schmidt TS, Bochenek ML, Sakakibara A, Adams S, Davy A, Deutsch U, Luthi U, Barberis A, Benjamin LE, Makinen T, Nobes CD, Adams RH (2010) Ephrin-B2 controls VEGF-induced angiogenesis and lymphangiogenesis. Nature 465:483-486 